Provided for non-commercial research and education use. Not for reproduction, distribution or commercial use.

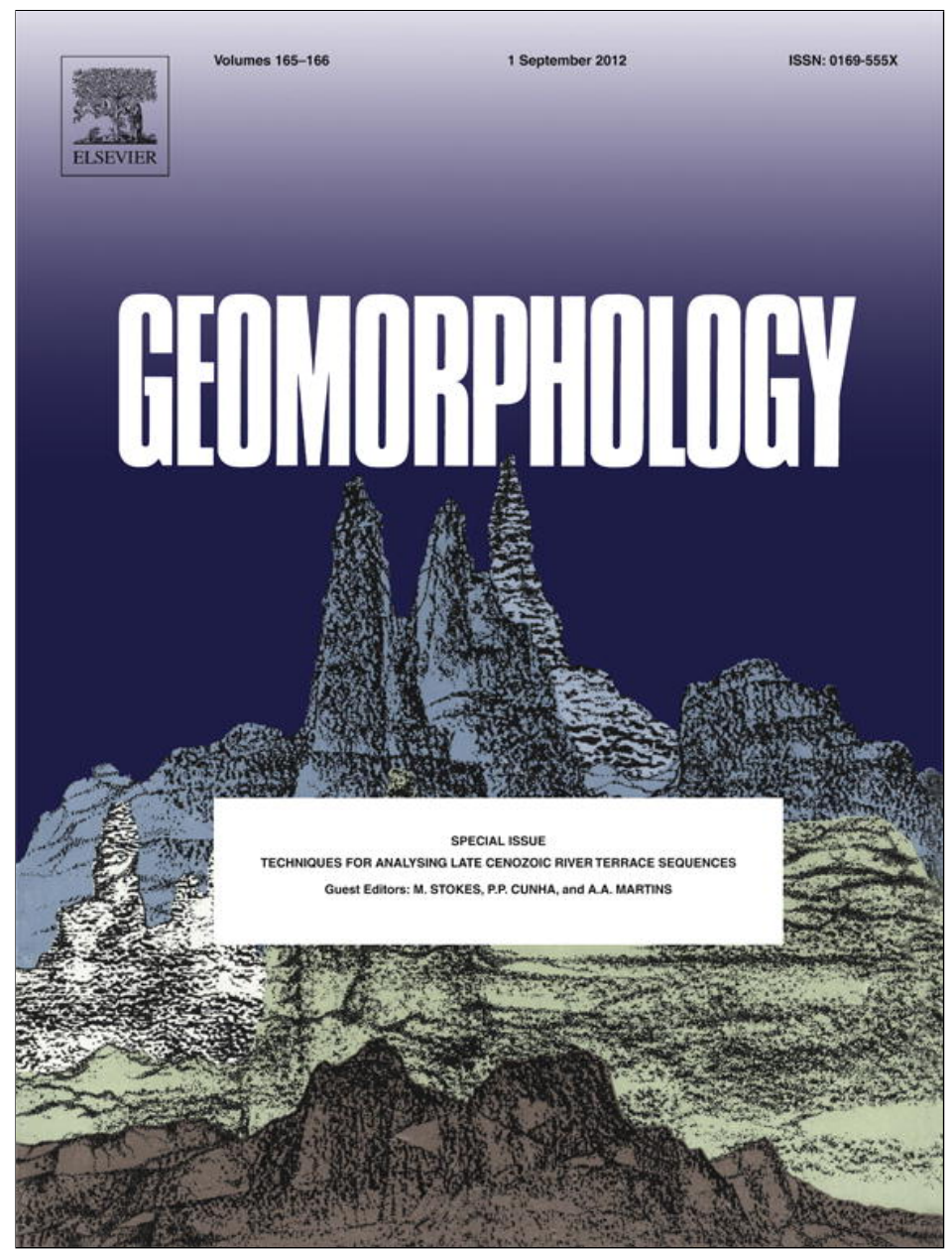

This article appeared in a journal published by Elsevier. The attached copy is furnished to the author for internal non-commercial research and education use, including for instruction at the authors institution and sharing with colleagues.

Other uses, including reproduction and distribution, or selling or licensing copies, or posting to personal, institutional or third party websites are prohibited.

In most cases authors are permitted to post their version of the article (e.g. in Word or Tex form) to their personal website or institutional repository. Authors requiring further information regarding Elsevier's archiving and manuscript policies are encouraged to visit:

http://www.elsevier.com/copyright 
Editorial

\section{Techniques for analysing Late Cenozoic river terrace sequences}

\section{Introduction}

This special edition presents a thematic set of eight papers examining field survey, remote sensing, and dating techniques used to analyse and interpret river terrace sequences. Most river systems from around the world have terrace landforms preserved at different altitudes along their valley sides. These landform sequences commonly span the Late Cenozoic encompassing hundreds of thousands to millions of years, providing an archive of long term fluvial landscape development and its driving mechanisms (Bridgland and Westaway, 2008a; Gibbard and Lewin, 2009; Westaway et al., 2009). River terrace sequences are an increasingly popular focus of earth science research (Vandenberghe et al., 2010). Whilst many collections of river terrace sequence research papers have primarily considered the environmental significance of such records (e.g. Vandenberghe and Maddy, 2000; 2001) less attention has been paid to the techniques used to collect the data. Thus, the purpose of this special issue is to bring together a set of research papers that demonstrate the multidisciplinary nature of river terrace sequence research. The special edition is also linked to two other research papers (Stokes et al., 2012; Veldkamp et al., 2012) that were incorrectly published as part of the normal research paper editions of Geomorphology.

This editorial firstly provides an overview of river terrace sequence research providing definitions and explanations of key aspects of river terrace sequence formation. An overview of the key research groups that have been studying river terrace sequences in recent years is then provided. Finally, an introduction to the principal techniques used for river terrace sequence research is given, with brief overviews of the papers that form and are linked to this special issue.

\section{River terrace sequences}

\subsection{Introduction}

River terraces comprise sediment deposited in former river channel and floodplain areas of valley floors and tributary streams (Green and McGregor, 1987; Lewin and Gibbard, 2010). A terrace is formed by river incision into the channel and floodplain sediments, leaving behind a body of fluvial sediment preserved along river channel margins or valley sides. River terraces tend to be visible within a landscape due to a relatively flat surface that grades topographically towards the valley centre and in a downstream direction. Terrace morphology can be modified and masked through burial/erosion by slope and/or tributary stream/alluvial fan processes.

River terraces consisting of erosional bedrock surfaces with a minor cover of gravels are usually referred to as strath terraces
(Leopold et al., 1964). These contrast with terraces developed within channel and floodplain sediments which are termed fill terraces (Leopold et al., 1964). Fill terraces can develop through complex incision and aggradation patterns (Lewin and Gibbard, 2010). Both strath and fill terraces can form inset sequences sometimes referred to as terrace flights or staircases. Many river systems from around the world display flights of river terrace landforms (Bridgland and Westaway, 2008a). The number of terrace levels can differ significantly along the length of a river system but generally terraces are absent or limited in number in areas where rivers cut across resistant bedrock, especially where river gorges or deeply dissected bedrock reaches occur (e.g. Martins et al., 2009). Such river terrace sequences typically span time periods of several tens to hundreds of thousands of years or longer (Bridgland and Westaway, 2008a; Gibbard and Lewin, 2009; Westaway et al., 2009).

\subsection{Climatic controls on river aggradation and incision patterns}

The formation of a river terrace requires aggradation of channel and floodplain sediments, followed by incision into the valley floor. A series of well established models of climate-related controls on sediment aggradation and incision exist for a range of climatic settings (e.g. Bull, 2009: arid/semi-arid; Gibbard and Lewin, 2002: temperate). The general tenet is that sediment aggradation commonly reflects periods of valley side slope instability where limited vegetation cover promotes soil erosion and an increased sediment supply to the valley floor. In contrast, fluvial incision occurs when valley sides become stabilised due to enhanced vegetation cover and a reduced sediment supply to the valley floor.

Throughout the Quaternary, fluvial aggradation is generally considered to have occurred during glacial periods, whilst incision occurs during interglacials (e.g. Vandenberghe, 2008). However, many researchers have questioned the over simplification of such models, highlighting the complexities of the timescales of climatefluvial landscape responses and the fact that many periods of fluvial aggradation and incision occur during glacial-interglacial transition periods or even during the brief warm interludes (interstadials) within a given glacial period (e.g. Bridgland and Westaway, 2008b and references therein). The differences of opinion probably reflect a combination of the contrasting climatic setting of case studies, preferential preservation issues of river terrace sequences located within glacial limits, and, in the case of Holocene terrace sequences, the increasing impacts of human activity upon a fluvial landscape. For example, higher latitude and temperate climate settings of glaciated regions in northwest Europe will differ in aggradation/incision styles and timing when compared to lower latitude and drier settings of non-glaciated Mediterranean regions (e.g. Bridgland and Westaway, 
2008b). Furthermore, terrace formation in valleys within glacial limits may be restricted to a single Late Pleistocene terrace (post Last Glacial Maximum) since older terraces will have been destroyed by valley glacier movements. Finally, terrace sequences that develop during the Holocene can also reflect climate variability but in many instances reflect sediment yield variations related to human-induced vegetation clearance (e.g. Houben et al., 2008, and references therein). Resolving these kinds of issues requires attempts at linking long term (i.e. spanning several glacial cycles) high resolution local/ regional climate data (e.g. vegetation records from pollen from lake/ lagoon cores, precipitation and temperature records from speleothems) to well-dated river terrace records. In particular, it requires a detailed understanding of the alluvial architecture of a river terrace and targeted sampling for absolute dating in order to show whether the terraces were built by vertical aggradation or lateral accretion (see Lewin and Gibbard, 2010 for discussion).

\subsection{River terrace staircase development}

Whilst climate provides an important control on channel and floodplain aggradation and incision patterns leading to the development of an individual terrace level, the formation of multiple inset river terrace levels within a staircase requires a sustained base level lowering trend. Base level is the lowermost point within a landscape that a river can erode to, with ultimate base level being sea level (Leopold and Bull, 1979). Changes in base-level will result in a river modifying its form through aggradation or incision both as a consequence of the tendency for the river to re-equilibrate its gradient. For a given time interval, a river will have a series of localised base levels along its length. For example, where a river crosses a fault, where a change in bedrock lithology occurs or where a tributary junction joins the trunk drainage. These localised base-level changes manifest themselves as steps in river long profiles, either as a single step termed a knick point or a series of steps called a knick zone. Incision tends to occur in steeper reaches around the knick point/zone and aggradation immediately downstream, both as a consequence of attempts by a river to equilibrate the gradient. However, the fact that the majority of river systems around the world show terrace development over significant distances of their lengths implies that regional base-level lowering trends are apparent. These are commonly attributed to tectonic uplift, climate or relative changes in sea-level, driven by either tectonics or climate (Bridgland and Westaway, 2008a,b; Gibbard and Lewin, 2009).

Over longer term (geological) timescales (commonly millions of years), regional base-level lowering is attributed to spatial and temporal variability of regional tectonic uplift rates. These rates can vary depending upon the proximity of river systems to plate boundary settings. Higher uplift rates tend to be associated with compressive plate boundary settings, especially those associated with collisional margins. Such areas are where base-level changes are of sufficient magnitude to provide terraces with wide altitudinal spacing (e.g. Starkel, 2003). Areas that are located away from plate margin settings (e.g. continental interiors) tend to have lower uplift rates and are more likely to have limited base-level changes that in turn result in restricted opportunities for terrace formation. Where terraces do form, they tend to have much closer altitudinal spacing (e.g. Starkel, 2003). Areas of lower tectonic uplift tend to relate to lithospheric thermal properties, thickness and age, with older, thicker and colder lithosphere being less mobile and thus showing subdued uplift (e.g. Westaway et al., 2009). Direct evidence of deformation through folding and faulting of terrace landforms is commonly absent or where present, is typically localised leading to complications in terrace stratigraphy and correlation difficulties (e.g. Martins et al., 2009). Many examples of research have used river terraces as geomorphic markers to quantify fluvial incision amounts and rates in tectonically active areas, and in some instances, it has even been argued that fluvial incision can be used as a proxy for quantifying uplift rates (e.g. Maddy et al., 2000).

In tectonically quiescent areas, regional base-level changes can be influenced by climate-related changes in sea level. The simple model for icehouse periods such as the Quaternary is that sea levels are low during cold glacial periods and high (or higher) during interglacial periods. Falling sea levels during climate cooling promote incision whilst rising sea levels during climate-related warming leads to aggradation, with both responses occurring within the distal end of the system only. The proximity of a fluvial system to the coast and the morphology of coastal shelf regions appear to be important factors. For example, Blum and Tornquist (2000) argue that for large river systems such as the Mississippi (typically comprising fill terraces) that drain low gradient continental interiors with expansive shelf margins, climate-related sea-level change does not affect areas much beyond $200 \mathrm{~km}$ from the coastline. For steeper gradient coastlines that are commonly characterised by strath terraces, where the shelf is narrow and often marked by a pronounced shelf break, the landwards impact of base-level changes are reduced, or in some instances, the fluvial system appears to become disconnected from sea level (e.g. Meikle, 2009). A major problem with climate related sea-level change as a principal controlling factor for terrace staircase formation is that it doesn't provide a sustained base-level lowering pattern of sufficient magnitude, at least during the Middle-Late Quaternary. In other words, sea level simply fluctuates between a minimum glacial lowstand level $(-120$ to $-160 \mathrm{~m})$ and a maximum interglacial highstand level $(+6 \mathrm{~m})$ (Rabineau et al., 2006). A sustained baselevel lowering can only be invoked if a Pre-Quaternary timescale for terrace staircase formation is included, for example including the warmer Pliocene climate when sea-level was considered to be approximately $+60 \mathrm{~m}$. (Dowsett et al., 1996). However, most methods routinely used to date river terrace sequences are limited to $100-300 \mathrm{ka}$ (e.g. luminescence dating). Techniques such as cosmogenic dating could be applied to the higher and older terrace levels with a sequence but problems with erosion rates and assumptions of cosmic ray flux and production rates are yet to be resolved (Cockburn and Summerfield, 2004). Only terrace records buried by lava flows provide opportunities for accurate dating of early Quaternary or older landform records (e.g. Veldkamp et al., 2012).

Tectonics clearly provides a convincing explanation for a sustained long term base-level lowering mechanism during the Late Cenozoic. However, climate-related variations in sediment supply are required for fluvial aggradation. Thus, flights of river terrace landforms appear to be the product of long term tectonic uplift with superimposed shorter term climate variability. However, complications exist with such a model and there is growing evidence to suggest that climatic changes affecting the surface (loading/unloading of sediment and water during glacial/interglacial cycles) are coupled to the sub-surface where changes in mantle flow magnitudes and directions occur (Westaway, 2001). This is therefore a climate-related mechanism for generating surface uplift resulting in fluvial incision and river terrace staircase formation and further highlights the complexities of unravelling climate-tectonic interactions for fluvial landscape development.

Climate can further complicate the interpretation of river terrace sequences, especially in river valleys that have been glaciated. The advance and retreat of valley glaciers has a high potential to destroy terrace landforms and caution should be used when analysing river terrace sequences in such areas.

\section{River terrace sequence research}

In recent years, a significant proportion of the previously outlined aspects of research into river terrace sequence records have been undertaken by scientists affiliated to a number of formal and informal groups. The papers in this special edition form research output from one such group, the 'Fluvial Archives Group' (FLAG). FLAG is an 
informal international group of geomorphologists, geologists, Quaternary scientists and archaeologists with a broad interest in river activity during the recent geological record (Late Cenozoic). A key focus of FLAG research is river terrace landforms. This research uses the spatial and temporal distribution of river terrace landforms and information derived from the sediment, soil, fossil and archaeological data contained within them as archives of environmental changes and landscape development.

FLAG began in 1996 as an affiliate to the UK Quaternary Research Association (QRA, 2012) and the broader international Quaternary science community of INQUA (INQUA, 2012). Since its inception it has held regular biennial meetings in locations throughout Europe (Table 1). The meetings have provided an opportunity for scientists and research students to present their latest ideas on fluvial landscape research in a relaxed and informal setting that many of the larger, established congresses do not necessarily allow. Each meeting showcases the fluvial landscape of the host country by a short field trip enabling lively and informative debates about the interpretation of key field sections, the techniques used to describe/ quantify fluvial records and many of the broader issues concerning controls on fluvial landscape development. As a consequence, many scientists from all over the world have experienced the opportunity to examine firsthand the exceptional fluvial landscape records of some Europe's (and the world's) key river systems such as the Rhine (Germany), Thames (UK), Danube (Hungary) and the Tejo (Portugal) amongst others. In addition to the biennial meetings, FLAG regularly contributes thematic sessions/symposia to some of the larger international congresses/meetings including the European Geosciences Union (EGU, 2012), INQUA (2012) and the International Conferences on Fluvial Sedimentology (Table 1).

The activities of FLAG have resulted in a significant output of peerreviewed scientific research and review papers. These papers have formed collections of papers in special editions of many international journals and books published by leading international scientific publishers (Table 1). The papers included in this special issue were presented at the 2010 biennial meeting of the 'Fluvial Archives Group' (FLAG) held at Vila Velha de Ródão in Portugal during September 2010. This meeting featured a scientific programme of oral and poster presentations followed by a three day field excursion along the River Tejo from Vila Velha de Ródão to Lisbon.

\section{Techniques for analysing river terrace sequences}

The analysis of river terrace sequences requires the application of a broad range of techniques involving computer-based remote sensing and modelling, fieldwork and laboratory methods. Ideally, these techniques should be integrated where appropriate. The papers presented in this special edition (including two other papers published in Geomorphology but presented at the 2010 FLAG meeting: Stokes et al., 2012; Veldkamp et al., 2012) showcase many aspects of these techniques and further demonstrate how river terrace sequences can be used to explore the interplay of tectonicclimatic driving mechanisms for fluvial landscape development. Furthermore, a growing area of river terrace research is archaeology,

Table 1

Activities of the Fluvial Archives Group and related organisations and their research publication outputs

\begin{tabular}{|c|c|}
\hline Meeting (Location, month, year) & Published outcomes \\
\hline Inaugural FLAG Discussion Meeting, Durham, UK, December 1996 & - \\
\hline FLAG 1997 Meeting, Arcen, the Netherlands, September 1997 & Special Issue, Geomorphology (Vandenberghe and Maddy, 2000) \\
\hline FLAG 1998 Meeting, Cheltenham, UK September 1998 & Edited Volume, Balkema (Maddy et al., 2001) \\
\hline 25th INQUA Congress, Durban, South Africa, August 1999 & Special Issue, Quaternary International (Vandenberghe and Maddy, 2001) \\
\hline FLAG 2000 Meeting, Mainz, Germany, March 2000 & Special Issue, Netherlands Journal of Geosciences(Bridgland and Sirocko, 2002) \\
\hline 1st IGCP 449 Plenary Meeting, Prague, Czech Republic, April 2001 & Collection of papers, Proceedings of the Geologists Association (Bridgland et al., 2004) \\
\hline 2nd IGCP 449 Plenary Meeting, Kanpur, India, December 2001 & Collection of papers, Current Science, New Delhi (Volume 84, Issue 8, 2003) \\
\hline FLAG/GLOCOPH/IGCP 449 Meeting, Wollongong, Australia & - \\
\hline 7th ICFS Congress, Lincoln, Nebraska, USA, July, 2001: FLAG sponsored session & Special Issue, Quaternary Science Reviews (Van Balen et al., 2003) \\
\hline 5th IAG Congress, Tokyo, Japan, August 2001: FLAG Sponsored symposia & Special Issue, Quaternary Science Reviews (Van Balen et al., 2003) \\
\hline FLAG workshop, Haarlem, The Netherlands, 2001 & Special Issue, Quaternary Science Reviews (Van Balen et al., 2003) \\
\hline FLAG 2002 Meeting, Clermont-Ferrand, France, September 2002 & Special Issue, Quaternaire (Pastre et al., 2004) \\
\hline 3rd IGCP 449 Plenary Meeting, Agadir, Morocco, December 2002 & Special issue, Global and Planetary Change (Westaway et al., 2009). \\
\hline 26th INQUA Congress, Reno, USA, July 2003; FLAG/GLOCOPH co-sponsored session & - \\
\hline 4th IGCP 449 Plenary Meeting, Belem, Brazil, June 2003 & Single paper in South American Journal of Earth Sciences (Westaway, 2006). \\
\hline FLAG 2004 Meeting, Sienna, Italy, September 2004 & Special Issue, Quaternary International (Coltorti and Pieruccini, 2008) \\
\hline Final IGCP 449 Plenary Meeting, Malaga, Spain, December 2004 & Special Issue, Quaternary Science Reviews (Bridgland et al., 2007) \\
\hline FLAG/GLOCOPH/LUCIFS Joint Meeting, Bonn, Germany, May 2005 & Special Issue, Geomorphology (Herget et al., 2007) \\
\hline $\begin{array}{l}\text { European Geoscience Union (EGU) Symposium, Vienna, April 2005; } \\
\text { FLAG/GLOCOPH co-sponsored session }\end{array}$ & Special Issue, Geomorphology (Vandenberghe and Vanacker, 2008) \\
\hline FLAG 2006 Meeting, Izmir, Turkey, September 2006 & - \\
\hline $\begin{array}{l}\text { IGCP } 518 \text { Plenary Meeting, Nanjing (session of CHINQUA) and } \\
\text { excursion to the Middle Yangtze, October } 2006\end{array}$ & Special Issue, Global and Planetary Change (Westaway et al., 2009) \\
\hline $\begin{array}{l}\text { 27th INQUA Congress, Cairns, Australia, July-August 2007; } \\
\text { FLAG/GLOCOPH co-sponsored session }\end{array}$ & - \\
\hline IGCP 518 Plenary Meeting, Sanliurfa, Turkey, September 2008 & Special Issue, Global and Planetary Change (Westaway et al., 2009) \\
\hline FLAG 2008 Meeting, Budapest, Hungary, & Special Issue, Proceedings of the Geologists Association (Vandenberghe et al., 2010) \\
\hline $\begin{array}{l}\text { 7th International Conference on Geomorphology, Melbourne, } \\
\text { Australia, July 2009; FLAG/GLOCOPH co-sponsored session }\end{array}$ & - \\
\hline FLAG 2010 Meeting, Vila Velha de Ródão, Portugal, September 2010 & Special Issue, Geomorphology (Stokes et al., this issue) \\
\hline
\end{tabular}

- FLAG = Fluvial Archives Group (informal group of scientists founded in 1996).

- GLOCOPH = Global Continental Palaeohydrology (a former sub-commission of INQUA; now a focus group of the INQUA Terrestrial Processes, Deposits and History [TERPO] commission).

- INQUA = International Union for Quaternary Research (formal group founded in 1928: INQUA, 2012).

- IAG = International Association of Geomorphologists (IAG, 2012).

- IGCP = International Geoscience Programme (a co-operative enterprise of the United Nations Educational, Scientific and Cultural Organization [UNESCO, 2012] and the International Union of Geological Sciences [IUGS, 2012]).

- LUCIFS = Land Use and Climate Impacts on Fluvial Systems (a network within the Past Global Changes [PAGES] core project of the International Geosphere-Biosphere Programme [IGPB]). 
whereby dating of terrace sediments that contain archaeological remains is providing an increased understanding of the environmental and climatic changes and their timings that influenced early humans.

The first steps for analysing river terrace sequences are to investigate the spatial distribution of landforms and to construct a relative landform stratigraphy. This can be achieved through remote sensing by using topographic maps, geological maps, aerial photography, satellite imagery and digital elevation model (DEM) datasets. In this issue Demir et al. utilise a range of remote sensing approaches and outline an approach for constructing improved quality/resolution topographic maps using Shuttle Radar Topography Mission (SRTM) DEM data onto which terrace landforms of the River Euphrates in SE Turkey were mapped. Digital datasets for use in river terrace sequence studies are becoming routinely used as data layers within Geographical Information Systems (GIS) for visualisation and data interrogation purposes. Bridgland et al. in their regional river terrace study of the River Orontes in Syria use a GIS with SRTM DEM data and high resolution CORONA satellite aerial photographic imagery (declassified military imagery taken in the 1960s-1970s prior to agricultural expansion). Whilst remote sensing clearly provides essential topographic data for mapping river terrace sequences it also allows analysis of the modern drainage network and how its morphology can provide insights into long term fluvial landscape development. An example of this is presented by Anton et al. who have extracted long profiles of the River Duero and its tributaries in Iberia. The River Duero documents a major continental scale drainage network re-organisation. The research uses river long profiles from the uppermost parts of the catchment to model former landscape levels, providing insights into the early drainage, pre-capture landscape configuration.

The remote sensing of river terraces can allow a relative landform stratigraphy to be constructed. Ideally, field evaluation is required to confirm or refine the positions and numbers of river terrace levels allowing terrace maps, valley cross-sections and plotting of different terrace levels against the modern river long profiles using in height range diagrams. Field survey methods to evaluate the heights of river terrace bases and surfaces above the modern river bed commonly involve using Global Positioning Systems (GPS). Hand held GPS are cheap, portable and generally provide reasonable quality location coordinates. Altitude accuracy tends to be low and can be improved using more specialised (and therefore more expensive and longer to set up) differential GPS (dGPS) linked to a base station that has been set up at a location of a known altitude (e.g. bench mark/ trigonometric point). Once set up, dGPS can provide a very rapid survey method for terrace mapping and altitude surveying as demonstrated by Demir et al. and Bridgland et al. in their regional scale studies of the Euphrates and Orontes. Maddy et al., also use GPS and dGPS in their study of the Gediz terrace record in SW Turkey. Within this study, terraces are buried under basaltic lava flows. GPS and dGPS have been used in conjunction with a hand-held laser range finder to survey terrace bases and upper contacts with overlying basalts. The survey results have then been used to construct a series of stratigraphic cross-sections, enabling correlation between sites from which a series of palaeochannels have been reconstructed. These in turn have been used to evaluate differences in response of drainage to regional climate change patterns and localised diversions in relation to volcanic activity.

Once a stratigraphic framework has been constructed, the sedimentology of individual terrace levels can be analysed to provide further insights into terrace stratigraphy to either help regional correlation (lithostratigraphy) or for more detailed insights into how individual terrace levels have been constructed (e.g. vertical vs. lateral aggradation etc.: Lewin and Gibbard, 2010). The internal terrace stratigraphy can provide an exceptionally important framework for terrace dating sampling strategy (see below). The most common application of terrace sedimentology is to provide insights into fluvial style and information about the source areas from where sediment is being derived from within a drainage basin. Detailed logging of sections, using facies analysis and alluvial architecture methods supplemented with clast counting approaches, are well established techniques used for such purposes (e.g. Demir et al., Bridgland et al.,). A more novel approach of using river terrace sedimentology for palaeoflood hydrological purposes is presented by Stokes et al. (2012) using river terraces from the Río Almanzora in SE Spain. They use maximum clast size data and sedimentary bedform heights in conjunction with geomorphological parameters (e.g. channel width and slope values) as data inputs to a range of competence and regime based palaeoflood equations. An increase in palaeoflood magnitude through time is discussed in the context of climate related variations in precipitation (and therefore flood regime) and river capture related drainage network expansion.

Dating of river terraces is an area that has shown considerable advancement in recent years. Dating the timescales of fluvial landscape development allows rates of landscape change and specific landscape shaping events (e.g. periods of climate change) to be accurately established and quantified. Palaeontological and archaeological remains found within river terrace sediments are well established relative dating techniques, but require verification by absolute dating methods. Studies by Bridgland et al., of the Orontes system in Syria and Cunha et al., of the Tejo system in Portugal use palaeontological/archaeological data as a relative age control on terrace stratigraphy.

Many of the studies dealing with Late Pleistocene to Holocene river terraces use radiocarbon dating (conventional or AMS). However, Optically Stimulated Luminescence (OSL) dating has become the main absolute dating method applied to river terraces, especially for terrace with ages beyond the limits of the radiocarbon technique $(\sim 40-50 \mathrm{ka})$ or in areas where the lack of organic matter in terrace sediments presents problems for radiocarbon dating. The OSL technique determines the time since quartz and feldspar sand grains were last exposed to daylight and is routinely used to date terrace sediments of up to $200 \mathrm{ka}$ (Duller, 2004). Older terrace sediments can use OSL methods but these tend to rely on lower quality feldspar OSL age determinations, although significant improvements in dating accuracy is currently being developed (Buylaert, et al., 2012). Cordier et al. utilise OSL and the related technique of Electron Spin Resonance (ESR) dating and apply it to river terraces associated with the River Sarre (a right bank tributary of the Moselle River in NE France and SW Germany). The OSL dating provides age control for the younger LateMiddle Pleistocene terraces, enabling the terrace aggradation to be linked to glacial periods and incision to the glacial/interglacial transitions. The ESR dating provides a first attempt at establishing an age control for the Early-Middle Quaternary. Ramos et al., use OSL dating on a river sequence associated with distal reaches of the River Mondego in central Portugal. The OSL dating suggests that terrace staircase formation occurred over the Middle-Late Pleistocene and that glacio-isostacy is a principal control on fluvial incision and terrace aggradation patterns and timing. Cunha et al., use OSL dating of terrace and related aeolian and colluvial sediments for geoarchaeological purposes. They use the OSL ages to construct an absolute chronology that provides insights into the timing of early human activity and Late Pleistocene climate variability. Other methods used to date 'younger', typically Late Pleistocene terraces include the uranium series technique. Bridgland et al., apply this method to channel calcretes in the Orontes system to help provide some age control on the terrace sequence.

The dating of older river terraces (middle Pleistocene or older) has been a constant challenge in river terrace research, mainly due to the fragmentary and erosional nature of the landform record and age limitations of commonly used techniques. Some dating success using $\mathrm{K}-\mathrm{Ar}$ and $\mathrm{Ar}-\mathrm{Ar}$ methods has been achieved in areas of volcanism, 
where river terraces have been buried by or incise into basaltic lava flows. Demir et al., provide new $\mathrm{K}-\mathrm{Ar}$ results from the River Euphrates suggesting that the early evolution of the Euphrates can be dated to 10 Ma. Veldkamp et al. (2012) use Ar-Ar dating of phonolite flows to provide suggest that volcanic activity associated with the development of Mount Kenya had a significant role in blocking Pliocene drainage and the formation of lava dammed lakes at 3.89 and $2.81 \mathrm{Ma}$. Bridgland et al., and Maddy et al., utilise previously published $\mathrm{K}-\mathrm{Ar}$ and $\mathrm{Ar}-\mathrm{Ar}$ datasets to provide age control on the stratigraphy of the Orontes ( 6-4 Ma) and Gediz ( 1.2 Ma) systems. In areas lacking volcanism, cosmogenic exposure dating techniques offer a huge potential for river terrace sequence research. The technique involves measuring the accumulation of cosmogenic nuclides in the top 2-3 $\mathrm{m}$ of the Earth's surface in relation to interactions between cosmic rays and minerals such as quartz (Cockburn and Summerfield, 2004). Cosmogenic nuclide concentration can be interpreted as the time since a surface exposure event, such as incision into a river channel/floodplain setting and its isolation within a landscape as a river terrace. Anton et al., use cosmogenic dating $\left({ }^{10} \mathrm{Be}\right.$ and $\left.{ }^{20} \mathrm{Ne}\right)$ on high elevation granitic bedrock surfaces formed by fluvial erosion prior to incision and development of the Arribes gorge region of the River Duero in westcentral Iberia. The dating provides age constraints on incision rates during river formation and the timing of capture of the internally drained Iberian continental interior by drainage flowing to the Atlantic Ocean.

A final technique for analysing river terrace sequences that have developed over long timescales (spanning numerous climate cycles) is numerical modelling. This technique has been used to investigate the relationships between climate, tectonics and lower-crustal flow processes (e.g. Westaway, 2001). More recent modelling efforts have used data from river terrace sequences to explain differences in vertical uplift motions associated with areas of continental crust of different ages and strength (e.g. Bridgland and Westaway, 2008a,b; Westaway et al., 2009). For example, Westaway in this issue presents a new numerical model that accounts for transitions from uplift to subsidence and then back to uplift over hundreds of thousands of years. This modelling highlights the importance of river terrace records for providing controls and understanding on deformation of continental lithosphere in relation to different layered rheological scenarios.

\section{Acknowledgements}

The idea for the FLAG 2010 meeting in Portugal was conceived from a British Council/Acções Integradas Treaty of Windsor collaborative project awarded to Stokes, Cunha, Martins and others in 2008/ 2009 and a continuation project in 2009/2010. We thank the mayor of Vila Velha de Ródão for allowing usage of the town auditorium and providing hospitality for the conference delegates. The Geomorphology editors Adrian Harvey and Andy Plater, together with Karuna Narasimhan from Elsevier and the many reviewers are thanked for their input into the review and editorial support process of this special issue and related papers.

\section{References}

Blum, M.D., Tornquist, T.E., 2000. Fluvial response to climate and sea-level change: a review and look forward. Sedimentology 47, 2-48.

Bridgland, D.R., Sirocko, F., 2002. Preface: Special Issue arising from the meeting in Mainz, Germany, of the Fluvial Archive Group. Netherlands Journal of Geosciences/ Geologie en Mijnbouw 81, 263-264.

Bridgland, D.R., Westaway, R., 2008a. Preservation patterns of Late Cenozoic fluvial deposits and their implications: results from IGCP 449. Quaternary International 189, 5-38.

Bridgland, D.R., Westaway, R., 2008b. Climatically controlled river terrace staircases: a worldwide Quaternary phenomenon. Geomorphology 98, 285-315.
Bridgland, D.R., Tandon, S., Westaway, R., 2004. Global correlation of Late Cenozoic fluvial deposits (IGCP 449): proceedings of the inaugural meeting, Prague, April 21-24, 2001. Proceedings of the Geologists' Association 115, 97-99.

Bridgland, D.R., Keen, D., Westaway, R., 2007. Global correlation of Late Cenozoic fluvial deposits: IGCP Project No. 449. Quaternary Science Reviews 26, 2693-3016.

Bull, W.B., 2009. Geomorphic Responses to Climatic Change. Blackburn Press. 326 pp.

Buylaert, J.-P., Jain, M., Murray, A.S., Thomsen, K.J., Thiel, C., Sohbati, R., 2012. A robust feldspar luminescence dating method for Middle and Late Pleistocene sediments. Boreas10.1111/j.1502-3885.2012.00248.x.

Cockburn, H.A.P., Summerfield, M.A., 2004. Geomorphological applications of cosmogenic isotope analysis. Progress in Physical Geography 28, 1-42.

Coltorti, M., Pieruccini, P., 2008. Fluvial architecture and dynamics in rising mountain chains and related basins; tectonic, climatic influence and human impact: the FLAG-SEQS (Fluvial Archive Group-Subcommission for European Quaternary Stratigraphy) Siena Meeting. Quaternary International 189, 1-4.

Dowsett, H.J., Barron, J.A., Poore, R.Z., 1996. Middle Pliocene sea surface temperatures: a global reconstitution. Marine Micropaleontology 27, 13-25

Duller, G.A.T., 2004. Luminescence dating of Quaternary sediments: recent advances. Journal of Quaternary Science 19, 183-192.

European Geoscience Union, 2012. http://www.egu.eu2012 [accessed 24/02/2012]

Gibbard, P.L., Lewin, J., 2002. Climate and related controls on interglacial sedimentation in lowland Britain. Sedimentary Geology 151, 187-210.

Gibbard, P.L., Lewin, J., 2009. River incision and terrace formation in the Late Cenozoic of Europe. Tectonophysics 474, 41-55.

Green, C.P., McGregor, D.F.W., 1987. River terraces: a stratigraphical record of environmental change. In: Gardiner, V. (Ed.), International Geomorphology 1986 Part 1. Wiley, Chichester, pp. 977-987.

Herget, J., Dikau, R., Gregory, K.J., Vandenberghe, J., 2007. The fluvial system - past and present dynamics and controls. Geomorphology 92, 101-105.

Houben, P., Wunderlich, J., Schrott, L., 2008. Climate and long-term human impact on sediment fluxes in watershed systems. Geomorphology 108, 1-7.

IAG, 2012. International Association of Geomorphologists http://www.geomorph. org2012 [accessed 24/02/2012]

INQUA, 2012. The International Union for Quaternary Research. http://www.inqua org2012[accessed 24/02/2012].

IUGS, 2012. International Union of Geological Sciences http://www.iugs.org2012 [accessed 24/02/2012]

Leopold, L.B., Bull, W.B., 1979. Base level, aggradation and grade. Proceedings of the American Philosophical Society 123, 168-202.

Leopold, L.B., Wolman, M.G., Miller, J.P., 1964. Fluvial Processes in Geomorphology. Freeman, San Francisco. 522 pp.

Lewin, J., Gibbard, P.L., 2010. Quaternary river terraces in England: forms, sediments and processes. Geomorphology 120, 293-311.

Maddy, D., Bridgland, D.R., Green, C., 2000. Crustal uplift in southern England: evidence from the river terrace record. Geomorphology 33, 167-181.

Maddy, D., Macklin, M., Woodward, J. (Eds.), 2001. River Basin Sediments Systems: Archives of Environmental Change. Balkema, Rotterdam. 503 pp.

Martins, A.A., Cunha, P.P., Huot, S., Murray, A.S., Buylaert, J.-P., 2009. Geomorphological correlation of the tectonically displaced Tejo River terraces (Gavião-Chamusca area, central Portugal) supported by luminescence dating. Quaternary International 199, 75-91.

Meikle, C.D., 2009. The Pleistocene drainage evolution of the Río Almanzora, Vera Basin, SE Spain. Unpublished PhD thesis, University of Newcastle, UK. 210 pp.

Pastre, J.F., Maddy, D., Bridgland, D.R., Antoine, P., 2004. Fluvial Archives Group (FLAG) Meeting, Clermont-Ferrand, September 2002 Préface Quaternaire 15, 3-4.

QRA, 2012. Quaternary Research Association http://www.qra.org.uk2012[accessed 24/ 02/2012].

Rabineau, M., Berné, S., Olivet, J.-L., Aslanian, D., Guillocheau, F., Joseph, P., 2006. Paleo sea levels reconsidered from direct observation of paleoshoreline position during Glacial Maxima (for the last 500,000 yr). Earth and Planetary Science Letters 252, 119-137.

Starkel, L., 2003. Climatically controlled terraces in uplifting mountain areas. Quaternary Science Reviews 22, 2189-2198.

Stokes, M., Griffiths, J.S., Mather, A.E., 2012. Palaeoflood estimates of Pleistocene coarse grained river terrace landforms (Río Almanzora, SE Spain). Geomorphology $149-150,11-26$.

UNESCO, 2012. International Geoscience Programme (IGCP). http://www.UNESCO.org/ new/en/natural-sciences/environment/earth-sciences/international-geoscienceprogramme2012[accessed 24/02/2012].

Fluvial response to rapid environmental change. In: Van Balen, R.T., Vandenberghe, J., Kasse, K. (Eds.), Quaternary Science Reviews 22, 2053-2236.

Vandenberghe, J., 2008. The fluvial cycle at cold-warm-cold transitions in lowland regions: a refinement of theory. Geomorphology 98, 275-284.

Vandenberghe, J., Maddy, D., 2000. The significance of fluvial archives in geomorphology. Geomorphology 33, 127-130.

Vandenberghe, J., Maddy, D., 2001. The response of river systems to climate change. Quaternary International 79, 1-3.

Vandenberghe, J., Vanacker, V., 2008. Towards a system approach in the study of river catchments. Geomorphology 98, 173-175.

Vandenberghe, J., Cordier, S., Bridgland, D.R., 2010. Editorial: extrinsic and intrinsic forcing of fluvial development: understanding natural and anthropogenic influences. Proceedings of the Geologists' Association 121, 107-112.

Veldkamp, A., Schoorl, J.M., Wijbrans, J.R., Claessens, L., 2012. Mount Kenya volcanic activity and the Late Cenozoic landscape reorganisation in the upper Tana fluvial system. Geomorphology 145-146, 19-31.

Westaway, R., 2001. Flow in the lower continental crust as a mechanism for the Quaternary uplift of the Rhenish Massif, north-west Europe. In: Maddy, D. 
Macklin, M. Woodward, J. (Eds.), River Basin Sediment Systems: Archives of Environmental Change. Balkema, Abingdon, England, pp. 87-167.

Westaway, R., 2006. Late Cenozoic sedimentary sequences in Acre state, southwestern Amazonia: fluvial or tidal? Deductions from the IGCP 449 fieldtrip. Journal of South American Earth Sciences 21, 120-134.

Westaway, R., Bridgland, D.R., Sinha, R., Demir, T., 2009. Fluvial sequences as evidence for landscape and climatic evolution in the Late Cenozoic: a synthesis of data from IGCP 518. Global and Planetary Change 68, 237-253.

Martin Stokes

School of Geography, Earth and Environmental Sciences, University of Plymouth, Drake Circus, Plymouth, Devon, PL4 8AA,

United Kingdom

Corresponding author.

E-mail address: mstokes@plymouth.ac.uk.
Pedro P. Cunha

Department of Earth Sciences,

IMAR-Marine and Environmental Research Centre,

University of Coimbra, Portugal

António A. Martins

Centro de Geofisica, Dep. Geociências, University of Évora, Portugal 